\title{
Malignant transformation of aggressive osteoblastoma to ostesarcoma
}

\author{
Agresif osteoblastomun osteosarkoma malign transformasyonu
}

\author{
Ömer Görgün, MD., ${ }^{1}$ Ahmet Salduz, MD., ${ }^{2}$ Rejin Kebudi, MD., ${ }^{1}$ \\ Harzem Özger, MD., ${ }^{2}$ Bilge Bilgiç, MD. ${ }^{3}$ \\ ${ }^{1}$ Division of Pediatric Oncology, İstanbul University, Oncology Institute, İstanbul, Turkey \\ ${ }^{2}$ Department of Orthopedics and Traumatology, İstanbul University, İstanbul Medical Faculty, İstanbul, Turkey \\ ${ }^{3}$ Department of Pathology İstanbul University, İstanbul Medical Faculty, İstanbul, Turkey
}

\begin{abstract}
Osteoblastoma is a rare, bone-forming tumor, characterized by osteoid and woven bone production. A 13-year old boy patient presented to our clinic with complaint of pain in his left proximal tibia. We performed curettage and bone grafting for the lesion diagnosed as osteoblastoma. Two years later, the patient admitted to the hospital with a mass in the same region which was diagnosed by biopsy to be osteosarcoma. Patient was performed reconstruction operation with local resection and mega prosthesis. Fourteen months after termination of chemotherapy, lung metastasis developed and the patient died consequently. In this article, we reported a patient with aggressive osteoblastoma of the left proximal tibia which recurred as an osteosarcoma and discussed the difficulties in the histopathological diagnosis and management of these patients. As some other cases in the literature, our case indicates that osteoblastomas may undergo malignant transformation.
\end{abstract}

Keywords: Malignant transformation; osteoblastoma; osteosarcoma.

Several bone abnormalities which range from normal variations, benign neoplasms, and reactive conditions to highly malignant tumors may occur in a developing skeleton.

Osteoblastoma is a rare, bone forming tumor, characterized by osteoid and woven bone production. One third of the lesions are located in the vertebral column, including the sacrum, but also other common sites of involvement include the long bones, especially the femur and the tibia. ${ }^{[1,2]}$
$\ddot{O} Z$

Osteoblastom osteoid ve örgümsü kemik üretimi ile karakterize, nadir, kemik oluşturan bir tümördür. On üç yaşında erkek hasta sol proksimal tibiasında ağrı yakınması ile kliniğimize başvurdu. Osteoblastom tanısı konulan lezyona küretaj ve kemik greftleme uygulandı. İki yıl sonra, hasta aynı bölgede kitle ile hastaneye başvurdu ve biyopside kitleye osteosarkom tanısı konuldu. Hastaya lokal rezeksiyon ve mega protez ile rekonstrüksiyon ameliyatı yapıldı. Kemoterapinin bitiminden 14 ay sonra, akciğer metastazı gelişti ve ardından hasta kaybedildi. $\mathrm{Bu}$ çalışmada sol proksimal tibiada osteosarkom şeklinde nüks eden agresif osteoblastomlu bir hasta sunuldu ve histopatolojik tanıdaki ve bu hastaların yönetimindeki zorluklar tartışıldı. Olgumuz, literatürdeki diğer bazı olgular gibi osteoblastomların malign transformasyon geçirebileceğini göstermektedir.

Anahtar sözcükler: Malign transformasyon; osteoblastom; osteosarkom.

The spectrum of osteoblastic tumors with overlapping characteristics between conventional, benign osteoblastomas and fully malignant osteosarcomas complicates both the diagnosis and the management of these tumors.

Herein, we report a case of aggressive osteoblastoma of the left proximal tibia which recurred as an osteosarcoma, and discuss the difficulties in the histopathological diagnosis and management of these patients. ${ }^{[3]}$

- Received: July 15, 215 Accepted: November 19, 2015

- Correspondence: Rejin Kebudi, MD. İstanbul Üniversitesi Onkoloji Enstitüsü Çocuk Sağlığı ve Hastalıkları Anabilim Dalı, Çocuk Onkoloji Bilim Dalı, 34390 Çapa, Fatih, İstanbul, Turkey. Tel: +90 212 - 5313100 Fax: +90 212 - 5348078 e-mail: rejinkebudi@hotmail.com 


\section{CASE REPORT}

A 13-year-old boy was admitted to a local hospital in January 1998 with pain in his left knee. Plain radiographs and computed tomography $(\mathrm{CT})$ revealed a $10 \times 10 \mathrm{~cm}$ lytic lesion in the proximal left tibia (Figure 1). A whole body bone scan with technetium-99 (Tc-99) showed enhanced activity in the left tibia. A core biopsy tru-cut was performed. The pathologic diagnosis was aggressive osteoblastoma. There was no intra-articular involvement. The neurovascular bundle was posteriorly displaced, but was involved. The patient underwent curettage and bone grafting (Figure 2). No further treatment was given in the postoperative period. Incorporation of the grafts was obtained on the X-rays at the six month follow-up visit (Figure 3).

Two years later, the patient was admitted to the Department of Orthopedics, University of İstanbul because of pain and swelling in his left knee. Upon physical examination, a painful 9x9x10 $\mathrm{cm}$ mass was found to be present. Magnetic resonance imaging showed a $5 \times 7 \times 7.5 \mathrm{~cm}$ solid mass including cystic components in the proximal left tibia (Figure 4). There was cortical destruction and soft tissue involvement also. Complete blood cell (CBC) was normal, erythrocyte sedimentation rate (ESR) $(94 \mathrm{~mm} / \mathrm{h})$ and lactate dehydrogenase (LDH) $(572 \mathrm{U} / \mathrm{L})$ levels were elevated. Other biochemical values were within normal limits. In the whole body bone scan, there was enhanced activity in the proximal left tibia only. Computed tomography
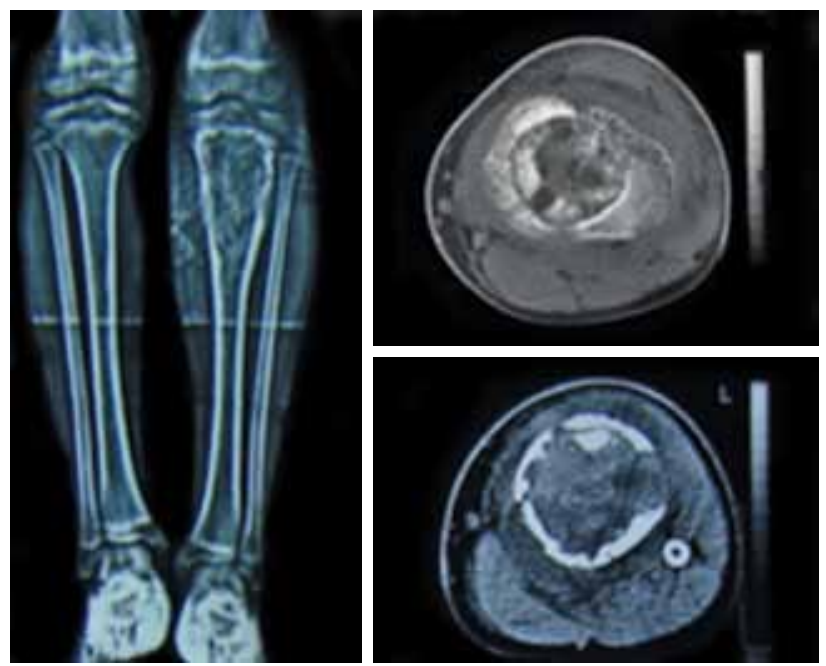

Figure 1. X-ray and axial computed tomography scan of the osteoblastoma at initial admission to the hospital. Note the, geographic circumscribed radiolucent lesion with expantion of bone, cortical thinning and cortical breakthrough. Computed tomography scan shows subtle calcification (egg shell rim of calcification) with intact periosteum. scan of the chest was normal. A biopsy was performed again and pathologic examination of the specimen revealed a grade II osteosarcoma including telangiectatic areas. Chemotherapy consisting of epirubicin $\left(90 \mathrm{mg} / \mathrm{m}^{2}\right.$, first day), ifosfamide $\left(1.8 \mathrm{~g} / \mathrm{m}^{2}\right.$, 1-3 days) and cisplatinum (100 $\mathrm{mg} / \mathrm{m}^{2}$, fourth day) was initiated.

By the end of the first course of chemotherapy, there was a very rapid local progression with tumor protruding through the skin. A written informed consent was obtained from the patient. The patient underwent a local resection and reconstruction with mega prosthesis (Figure 5). Pathology revealed telengiectatic osteosarcoma with $<15 \%$ necrosis according to Huvos criteria (Figure 6). Surgical margins were negative. There was no metastasis. The resection site was barely covered because of the wide resection site. Postoperatively there was a delay in the healing of the skin on the resection site. A skin graft was used, after which the patient had local wound infection and was treated with antibiotics according to culture results.

The patient received five courses of cisplatinum $\left(100 \mathrm{mg} / \mathrm{m}^{2} /\right.$ day $)$ and epirubicin $\left(90 \mathrm{mg} / \mathrm{m}^{2} /\right.$ day $)$ postoperatively. The patient experienced many difficulties throughout the course of treatment.

The boy had to be admitted for febrile neutropenia and local wound infection between chemotherapy courses. Pneumothorax on the right due to a bronchopleural fistula developed after the fourth course. Underwater drainage was used, but the condition did not improve. On the chest CT there was no lung metastasis, a bronchopleural fistula was diagnosed. The patient was operated on and the bronchopleural fistula was repaired.

Fourteen months after terminating chemotherapy, lung metastasis developed. An $11 \times 9 \times 10 \mathrm{~cm}$ mass on the right lung was
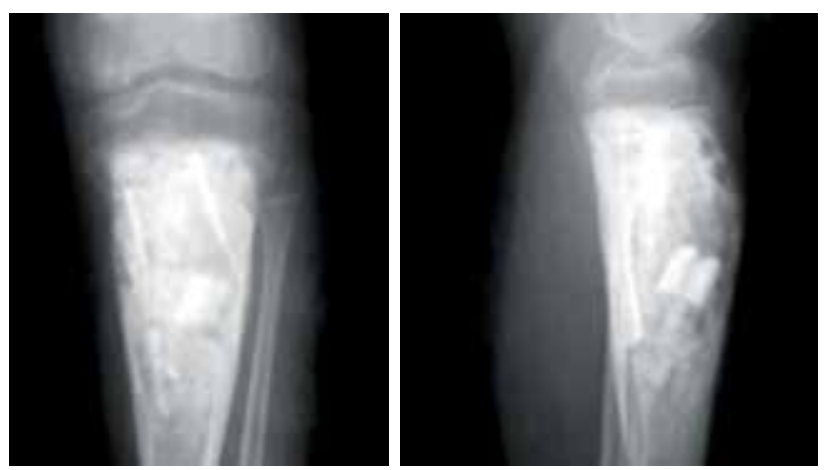

Figure 2. Anteroposterior and lateral X-ray imaging at four months after first operation (curettage and bone grafting). 

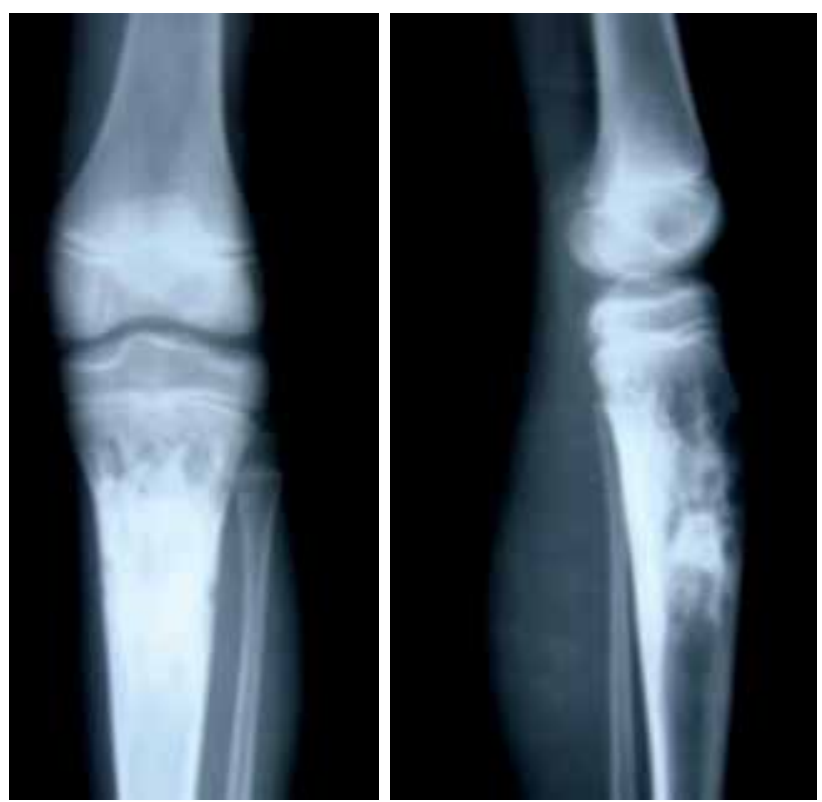

Figure 3. X-rays show that good incorporation with the bone at the sixth month postoperatively.

detected. Retrospectively, it was suspected that the bronchopleural fistula may have been a manifestation of an undetected micrometastasis. The metastasis could be removed totally by pneumonectomy and second line chemotherapy consisting of alternate courses of high dose methotrexate and ifosfamide was planned. After one course of chemotherapy with methotrexate $\left(12 \mathrm{~g} / \mathrm{m}^{2}\right)$,

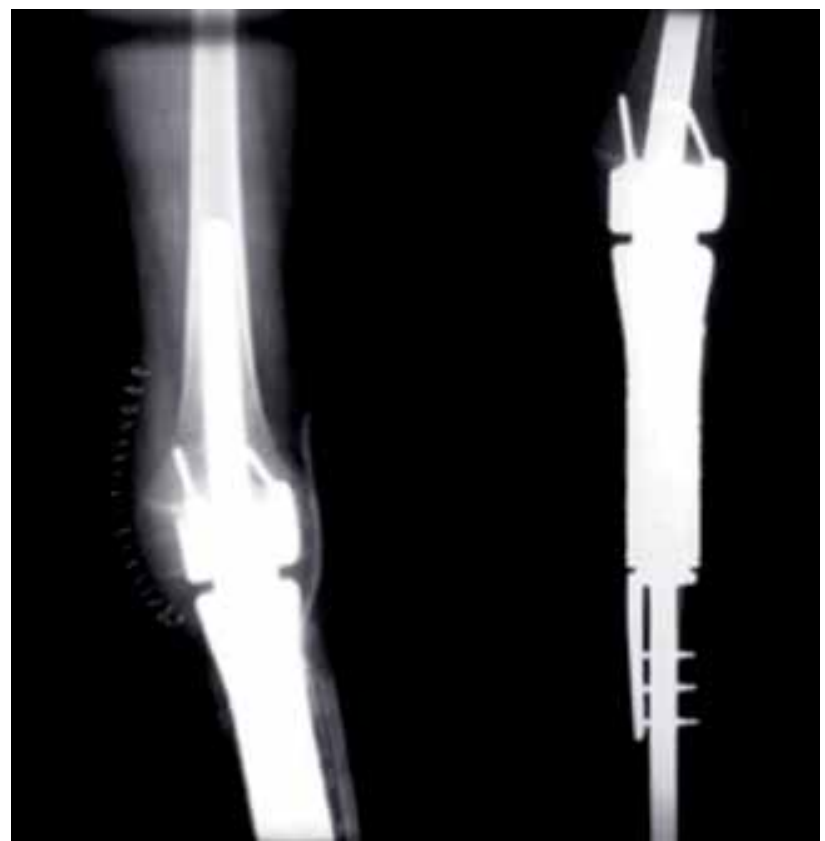

Figure 5. Wide resection and reconstruction with mega prosthesis was performed. Postoperative X-ray of the patient.
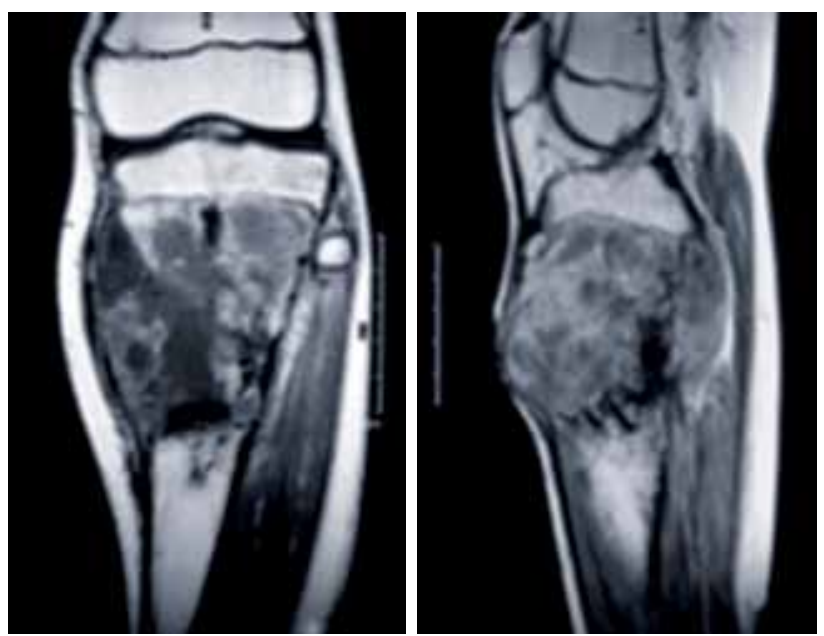

Figure 4. Magnetic resonance imaging shows cortical destruction, soft tissue involvement and progression of the lesion at two years postoperatively.

the patient and the family refused further treatment. After four months metastasis developed on the left lung and the patient died of the progressive disease.

\section{DISCUSSION}

Osteoblastoma is a rare tumor of the bone that consists of bony trabecula and osteoid. The overlapping characteristics of benign osteoblastomas and malignant osteosarcomas may complicate the diagnosis and management in some cases.

The pathology of osteoblastoma appears similar to that described for osteoid osteoma. The lesion is red if richly vascular or whitish yellow if it is more intensely made of bone. There is a sclerotic reaction around the tumor. Osteoblastomas may

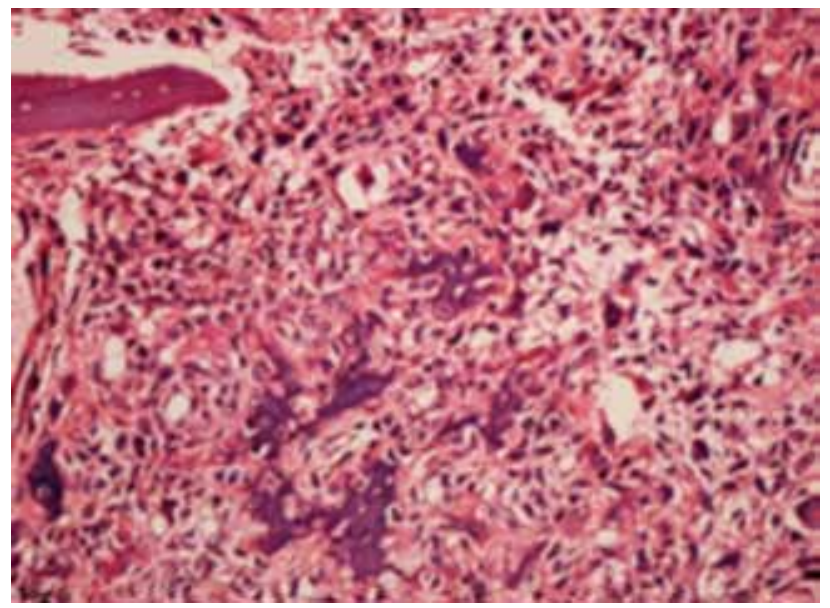

Figure 6. Histopathological appearance of the resected bone. It was seen that the malignant tumor cells that produce tumoral osteoid at the background H-E stain $\times 100$. 
have histologic variability. The classical appearance of osteoblastoma is characterized by pure osteoid and trabecular or woven bone production, not lamellar bone production, with variable numbers of osteoblasts within a fibrovascular stroma. The stroma of osteoblastomas is richly vascular and may show some degree of secondary aneurysmal bone cyst degeneration. Usually large osteoblasts are seen in conventional osteoblastomas which contain a large nucleus with a distinct nucleolus. Because of the variable histologic features, the pathologist must be experienced with distinguishing between osteoblastoma and osteosarcoma.

Dorfmann and Weiss classified osteoblastomas into four groups in 1984: ${ }^{[4]}$

1- Low-grade osteosarcomas (Osteoblastoma like osteosarcoma).

\section{2- Pseudomalignant osteoblastomas.}

3- Osteoblastomas that have undergone malignant transformation to osteosarcoma: ${ }^{[5]}$ This group is highly controversial. Although several case reports exist, ${ }^{[1,5-8]}$ including the present case. Some authors suggest that these should belong in the first group, osteoblastomalike osteosarcomas. ${ }^{[1]}$

4- Aggressive osteoblastoma: Aggressive osteoblastomas have characteristics intermediate between those of osteoblastoma and low-grade osteosarcoma. They define this group both clinically and histologically. None of these tumors have developed metastasis. But, recurrence may be commonly seen after surgery. In these tumors, mitotic activity is low, and no atypical mitosis is seen. In spite of the lack of recognized metastasis, Schajowicz and Lemos $^{[9]}$ defined Dorfman and Weiss's fourth group as malignant osteoblastoma. Lucas et al. ${ }^{[1]}$ agree with this notion and state that distinguishing osteoblastoma from osteosarcoma is sometimes impossible. They emphasize that the most reliable histologic factor is "destructive permeation" in osteosarcoma. ${ }^{[5]}$

A thorough microscopic examination for cellular atypia, nuclear atypia, abnormal mitoses or a permeative pattern is required for the diagnosis of osteoblastoma. Any of these factors suggest that the tumor is an osteosarcoma.

The recurrence rate is approximately $10 \%$ to $20 \%$ in conventional osteoblastoma. ${ }^{[1]}$ In nonvertebral lesions or with agressive osteoblastomas, the treatment may need to be more aggressive, consisting of either marginal or wide en bloc excision. In addition, some form of adjuvant such as chemical cauterization with phenol or cryosurgery may be considered. Good responses and long-term survival have been reported in limited recurrent and non-resectable cases with radiotherapy and/or chemotherapy. ${ }^{[10]}$

Osteosarcomas may resemble osteoblastomas. Bertoni et al. ${ }^{[1]]}$ reported a series of 11 osteosarcomas in patients aged 19-47 that histologically resemble osteoblastoma. In six patients the roentgenograms showed cortical destruction and poorly defined borders on the lesion that was suggestive of malignancy. Histologically, the tumor permeation of the surrounding host tissue allowed them to differentiate osteoblastoma-like osteosarcoma from osteoblastoma. The first diagnosis was benign in nine of the patients. Adequate surgical margins were not achieved in five patients of whom two died after inadequate surgical treatment of the primary tumor as well as from recurrences. The six patients who were treated with wide surgical margins were alive did not have any recurrences.

There are very few cases in the literature of patients who developed osteosarcoma after osteoblastoma. Kunze et al. ${ }^{[12]}$ reported a 57-yearold woman with an unusually fast-growing and destructive osteoblastic tumor on the left proximal humerus. During the histopathologic examination, most of the initial tumor revealed the characteristic morphologic features of a benign-appearing aggressive osteoblastoma. The definitive diagnosis was stated as an osteoblastoma with focal malignant transformation to well differentiated osteosarcoma. The proximal third of the humerus was resected en bloc. Five months after surgery, an extensive local soft tissue recurrence occurred. Eight months postoperatively, a further massive recurrent tumor and multiple pulmonary metastasis had developed. Chemotherapy caused a marked decrease in the size of soft tissue recurrences and the lung metastasis showed no further increase in their number and size. Osteoblastomas with conversion to osteosarcoma should be considered a separate clinicopathologic tumor entity distinguished from genuine osteosarcoma. All cases of malignantly transformed conventional and aggressive osteoblastomas reported to date have shown a conversion to low or high grade osteosarcomas only in recurrent tumors. The present case supports the concept that osteoblastomas may primarily undergo early malignant transformation. Osteoblastomas with conversion to osteosarcoma require an aggressive surgical approach followed by chemotherapy in the hope of prolonging life expectancy or obtaining a cure.

Grace et al. ${ }^{[13]}$ have confirmed the malignant transformation from osteoblastoma to osteosarcoma 
using DNA microdensity in tissue removed on four separate occasions from a lesion in the right femur of an 18 year old man. They performed a retrospective DNA analysis on tissue. Initial biopsy, which was diagnosed as osteoblastoma showed euploid DNA with a near diploid DNA model. The second biopsy specimen taken one month later also resembled osteoblastoma but showed an aneuploid DNA profile. The third biopsy specimen taken four months later showed histological evidence of osteosarcoma and a near pentaploid modal DNA with large number of nuclei exceeding. DNA microdensitometry confirmed the initial and final diagnosis.

At the histological level, the differential diagnosis of osteoblastic bone tumors is characterized by several problems that cannot be solved with conventional histological methods including immunohistology. Differentiating an aneurysmal bone cyst from a telangiectatic osteosarcoma is an example reflecting the complexity of this field. To develop a new approach to these diagnostic problems, Radig et al. ${ }^{[14]}$ analyzed the genetic instability which are mutations in the p53 gene and Ras gene, loss of heterozygosity at the p53, p16 and Rb locus, and amplification of c-myc gene in a large number of bone-forming tumor-like lesions as well as in benign and malignant osteoblastic tumors. The results of this study showed that the number of genetic alterations increases with the malignancy of the tumors. The highest number of genetic alterations could thus be found in conventional osteosarcoma. Analyzing genetic instability contributes to an improvement in the differential diagnosis of osteoblastic tumors.

Similar to other cases in the literature, the present case supports the concept that osteoblastomas may primarily undergo malignant transformation. Osteoblastomas with conversion to osteosarcoma require an aggressive surgical approach followed by chemotherapy in the hope of prolonging life expectancy or obtaining a cure.

\section{Acknowledgment}

We would like to thank the following pathologists of the Istanbul Bone and Soft Tumor Registry: Prof. Dr. Gülçin Erseven and Prof. Dr. Canan Alatlı, University of İstanbul, Oncology Institute, Division of Pathology; Prof. Dr. Misten Demiryont, University of Istanbul, Istanbul Medical Faculty, Department of Pathology for reviewing the pathological slides of the case. We also thank Norman Jaffe, MD from the University of Texas, MD Anderson Cancer Center for reviewing the manuscript.

\section{Declaration of conflicting interests}

The authors declared no conflicts of interest with respect to the authorship and/or publication of this article.

\section{Funding}

The authors received no financial support for the research and/or authorship of this article.

\section{REFERENCES}

1. Lucas DR, Unni KK, McLeod RA, O'Connor MI, Sim FH. Osteoblastoma: clinicopathologic study of 306 cases. Hum Pathol 1994;25:117-34.

2. McLeod RA, Dahlin DC, Beabout JW. The spectrum of osteoblastoma. AJR Am J Roentgenol 1976;126:321-5.

3. Bağatur AE, Yalçınkaya M. How to write a case report? or... not write at all? Eklem Hastalik Cerrahisi 2014;25:165-7.

4. Dorfman HD, Weiss SW. Borderline osteoblastic tumors: problems in the differential diagnosis of aggressive osteoblastoma and low-grade osteosarcoma. Semin Diagn Pathol 1984;1:215-34.

5. Merryweather R, Middlemiss JH, Sanerkin NG. Malignant transformation of osteoblastoma. J Bone Joint Surg [Br] 1980;62:381-4.

6. Figarella-Branger D, Perez-Castillo M, Garbe L, Grisoli F, Gambarelli D, Hassoun J. Malignant transformation of an osteoblastoma of the skull: an exceptional occurrence. Case report. J Neurosurg 1991;75:138-42.

7. Seki T, Fukuda H, Ishii Y, Hanaoka H, Yatabe S. Malignant transformation of benign osteoblastoma. A case report. J Bone Joint Surg [Am] 1975;57:424-6.

8. Ueno H, Ariji E, Tanaka T, Kanda S, Mori S, Goto M, et al. Imaging features of maxillary osteoblastoma and its malignant transformation. Skeletal Radiol 1994;23:509-12.

9. Schajowicz F, Lemos C. Malignant osteoblastoma. J Bone Joint Surg [Br] 1976;58:202-11.

10. Berberoglu S, Oguz A, Aribal E, Ataoglu O. Osteoblastoma response to radiotherapy and chemotherapy. Med Pediatr Oncol 1997;28:305-9.

11. Bertoni F, Bacchini P, Donati D, Martini A, Picci P, Campanacci M. Osteoblastoma-like osteosarcoma. The Rizzoli Institute experience. Mod Pathol 1993;6:707-16.

12. Kunze E, Enderle A, Radig K, Schneider-Stock R. Aggressive osteoblastoma with focal malignant transformation and development of pulmonary metastases. A case report with a review of literature. Gen Diagn Pathol 1996;141:377-92.

13. Grace J, McCarthy S, Stankovic R, Marsden W. Malignant transformation of osteoblastoma: study using image analysis microdensitometry. J Clin Pathol 1993;46:1024-9.

14. Radig K, Schneider-Stock R, Mittler U, Neumann HW, Roessner A. Genetic instability in osteoblastic tumors of the skeletal system. Pathol Res Pract 1998;194:669-77. 